\title{
Pengaruh Fluktuasi Harga Komoditas Pangan Terhadap Inflasi di Provinsi Sumatera Utara
}

\author{
Rahmanta $^{1^{*}}$ \\ S.F.Ayu ${ }^{2}$ \\ E.F. Fadhilah ${ }^{3}$ \\ R.S. Sitorus ${ }^{4}$ \\ 1,2 Program Studi Agribisnis Fakultas Pertanian, Universitas Sumatera Utara \\ 3,4 Alumni Magister Agribisnis Fakultas Pertanian, Universitas Sumatera Utara \\ *email : rahmanta@usu.ac.id \\ Diterima: Juli 2020, Disetujui:September 2020, Dipublish: Oktober 2020
}

\begin{abstract}
Abstrak
Perubahan harga komoditas pangan merupakan penyumbang terbesar laju inflasi di Provinsi Sumatera Utara. Inflasi di Provinsi Sumatera Utara mengalami perubahan naik turun. Tujuan penelitian ini menganalisis pengaruh fluktuasi harga beras, cabai merah, minyak goreng, daging ayam ras, telur ayam ras dan jagung terhadap inflasi di Provinsi Sumatera Utara. Model analisis yang digunakan adalah Vector Error Corection Model (VECM). Variabel yang digunakan adalah inflasi, harga beras, cabai merah, minyak goreng, daging ayam ras, telur ayam ras dan jagung. Data yang digunakan data sekunder mulai tahun 2013-2017 berupa data bulanan sehingga diperoleh data sebanyak 60 pengamatan. Hasil penelitian menunjukkan pada jangka pendek, inflasi bulan sebelumnya berpengaruh positif terhadap inflasi bulan sekarang, pada jangka pendek dan jangka panjang, harga beras berpengaruh positif terhadap inflasi bulan sekarang, pada jangka panjang, harga daging ayam ras berpengaruh positif terhadap inflasi bulan sekarang, pada jangka panjang dan jangka pendek, harga cabai merah berpengaruh positif terhadap inflasi bulan sekarang, pada jangka panjang, harga minyak goreng berpengaruh positif terhadap inflasi bulan sekarang, pada jangka panjang harga telur ayam ras berpengaruh positif terhadap inflasi bulan sekarang, pada jangka pendek dan jangka panjang, harga jagung tidak berpengaruh positif terhadap inflasi bulan sekarang.
\end{abstract}

Kata kunci: inflasi, harga komoditi pangan, VECM

\begin{abstract}
Changes in food commodity prices are the biggest contributor to the inflation rate in North Sumatra Province. Inflation in North Sumatra Province experienced ups and downs. The purpose of this study was to analyze the effect of price fluctuations in rice, red chilies, cooking oil, chicken meat, eggs and corn on inflation in North Sumatra Province. The analysis model used is the Vector Error Correction Model (VECM). The variables used are inflation, price of rice, red chilies, cooking oil, chicken meat, eggs and corn. The data used are secondary data from 2013-2017 in the form of monthly data so that 60 observations were obtained. The results showed that in the short run, the previous months inflation had a positive effect on the current months inflation, in the short and long term, rice prices have a positive effect on current month inflation, in the long run, the price of chicken has a positive effect on current month inflation, in the long term and short term, the price of red chili has a positive effect on current month inflation, in the long run, the price of cooking oil has a positive effect on current month inflation, in the long run, the price of chicken eggs has a positive effect on current month inflation, in the short and long term, corn prices do not have a positive effect on current month inflation.
\end{abstract}

Keywords: inflation, food comodity prices, VECM 


\section{PENDAHULUAN}

Fenomena fluktuasi harga pangan di Provinsi Sumatera Utara menjadi perhatian penting dibahas oleh pemerintah maupun pelaku ekonomi. Fluktuasi harga pangan tersebut dapat mempengaruhi inflasi di Indonesia, khususnya di Provinsi Sumatera Utara yang mengakibatkan naiknya harga komoditi pangan dan turunnya nilai mata uang. Apabila hal tersebut terjadi maka daya beli masyarakat menjadi menurun (BPS Sumatera Utara, 2018).

Inflasi adalah suatu kecenderungan mengenai harga naik pada umumnya dan secara terusmenerus. Ketika harga dari satu atau beberapa barang naik, maka itu bukanlah dapat dikatakan sebagai inflasi. Namun, apabila harga barang yang naik tersebut meluas dan mengakibatkan naiknya sebagian besar dari barang-barang lainnya itulah yang dinamakan dengan inflasi (Budiono, 2000).

Adanya ketidakseimbangan antara permintaan dan penawaran pangan memerlukan suatu kebijakan stabilisasi harga komoditas pangan. Laju inflasi yang tidak stabil juga menyulitkan perencanaan bagi dunia usaha, tidak mendorong masyarakat untuk menabung, dan berbagai dampak negatif lain yang tidak kondusif bagi perekonomian secara keseluruhan (Mankiw, 2005).

Ekonom aliran Keynesian berpendapat bahwa inflasi merupakan suatu gejala moneter. Dalam kajian yang dipelopori
Friedman dan dilanjutkan oleh berbagai kajian selanjutnya telah dapat menguji bahwa dalam jangka panjang terdapat keterkaitan yang erat antara inflasi dan jumlah uang yang beredar (Suseno, et.al. 2009).

Perubahan harga pada komoditas bahan pangan merupakan penyumbang terbesar laju inflasi di Indonesia. Dengan jumlah penduduk yang cukup besar, permintaan bahan pangan pun semakin meningkat, tetapi terkadang penawaran bahan pangan belum cukup memenuhi permintaan yang ada. Hal tersebut dapat meningkatkan harga bahan pangan yang akhirnya mendorong laju inflasi (Santoso, 2011).

Kelompok bahan makanan dikelompokkan menjadi beberapa sub-kelompok yaitu: padi-padian, umbi-umbian dan hasilnya, daging dan hasil-hasilnya, ikan segar, ikan diawetkan, telur, susu dan hasilhasilnya, sayur-sayuran, kacangkacangan, buah-buahan, bumbubumbuan, lemak dan minyak, serta bahan makanan lainnya (BPS Sumatera Utara, 2018).

Perubahan harga pada komoditas bahan pangan merupakan penyumbang terbesar laju inflasi Nasional, khususnya di Provinsi Sumatera Utara. Berdasarkan data yang diperoleh dari Badan Pusat Statistik (BPS) Provinsi Sumatera Utara bahwa inflasi di Provinsi Sumatera Utara pada tahun 2013 2019 mengalami fluktuasi naik turun.

Inflasi di Provinsi Sumatera Utara dihitung dari Indeks Harga Konsumen 
(IHK) bulanan. Perhitungan IHK bulanan Provinsi Sumatera Utara dilaksanakan di empat kota, yaitu Kota Medan, Kota Pematangsiantar, Kota Sibolga dan Kota Padangsidempuan dengan pertimbangan bahwa perekonomian di kota tersebut relatif pesat dibandingkan dengan kota-kota lain di Provinsi Sumatera Utara (BPS Sumatera Utara, 2018).

Rizaldy (2017) menganalisis tentang seberapa besar harga bawang merah berpengaruh terhadap inflasi pada jangka pendek dan jangka panjang, seberapa besar harga cabe rawit berpengaruh terhadap inflasi di Kota Malang pada jangka pendek dan jangka panjang dengan menggunakan metode deskriptif dan partial adjustment model (PAM). Pada hasilnya menunjukkan bahwa harga bawang merah berpengaruh signifikan terhadap inflasi baik dalam jangka pendek dan jangka panjang, serta harga cabe rawit berpengaruh signifikan terhadap inflasi di kota Malang baik dalam jangka pendek dan jangka panjang.

Kusnadi (2018) penelitian ini menggunakan metode analisis VARVECM. Hasil VECM menerangkan bahwa dalam jangka pendek fluktuasi harga komoditas cabai rawit dan bawang merah berpengaruh positif terhadap inflasi, sedangkan harga komoditas beras jenis mentik, daging sapi dan daging ayam berpengaruh negatif terhadap Inflasi. Dalam jangka panjang fluktuasi harga komoditas beras jenis metik, daging ayam dan cabai rawit berpengaruh positif terhadap inflasi, fluktuasi harga daging sapi dan bawang merah berpengaruh negatif terhadap inflasi di Provinsi Jawa Timur.

Perbedaan penelitian ini dengan penelitian terdahulu meliputi penggunaan variabel penelitian, periode, dan tempat penelitian. Penelitian ini menggunakan variabel inflasi, harga beras, cabe merah, cabe rawit, bawang merah dan bawang putih. Untuk alat analisis yang digunakan dalam penelitian ini adalah Vector Error Corection Model (VECM model). Selain itu, persamaan penelitian ini dengan penelitian terdahulu adalah sama-sama membahas tentang inflasi.

Berdasarkan uraian diatas peneliti tertarik untuk meneliti pengaruh fluktuasi harga komoditas pangan (harga beras, cabai merah, minyak goreng, daging ayam ras, telur ayam ras dan jagung) terhadap inflasi di Provinsi Sumatera Utara. Hal ini didasari keenam komoditi ini memberikan kontribusi yang sangat dominan terhadap perkembangan inflasi di Provinsi Sumatera Utara (BPS Sumatera Utara, 2018). Tujuan penelitian ini menganalisi pengaruh fluktuasi harga komoditas pangan (harga beras, cabai merah, minyak goreng, daging ayam ras, telur ayam ras dan jagung) terhadap inflasi di Provinsi Sumatera Utara.

\section{METODE PENELITIAN}

Data yang digunakan adalah data inflasi di Provinsi Sumatera Utara 
pada periode Januari 2013 hingga

Desember 2017 dan data perkembangan harga komoditas pangan bulanan pada tingkat konsumen di Provinsi Sumatera Utara pada periode Januari 2013 hingga Desember 2017. Data-data tersebut diambil dari Badan Pusat Statistik Provinsi Sumatera Utara dan Pusat Informasi Harga Pangan Strategi (PIHPS). Selain itu, berbagai data penunjang diperoleh dari buku bacaan, jurnal ilmiah dan artikel yang sesuai dengan topik penelitian.

Identifikasi pengaruh fluktuasi harga komoditas pangan (harga beras, cabai merah, minyak goreng, daging ayam, telur ayam ras dan jagung) di Provinsi Sumatera Utara periode Januari 2013 - Desember 2017 menggunakan analisis VAR (Vector Autoregretion). Variabel yang digunakan adalah fluktuasi harga bulanan komoditas pangan (beras, cabai merah, minyak goreng, daging ayam, telur ayam ras dan jagung) serta Inflasi Provinsi Sumatera Utara. Analisis VAR akan diolah menggunakan perangkat lunak Eviews 10. Masing-masing variabel menggunakan logaritma natural untuk memudahkan perhitungan. Model penelitian dapat ditulis sebagai berikut :

$\begin{aligned} \text { LnINFLASI }_{\mathrm{t}}= & \mathrm{a}_{0}+\mathrm{a}_{1} \text { LnInflasi }_{\mathrm{t}-1+}+ \\ & \mathrm{a}_{2} \mathrm{LnRice}_{\mathrm{t}}+ \\ & \mathrm{a}_{3} \mathrm{LnRC}_{\mathrm{t}}+\mathrm{a}_{4} \mathrm{LnCO}_{\mathrm{t}} \\ & +\mathrm{a}_{5} \mathrm{LnCM}_{\mathrm{t}}+ \\ & \mathrm{a}_{6} \mathrm{LnBE}_{\mathrm{t}}+ \\ & \mathrm{a}_{7} \mathrm{LnCorn}_{\mathrm{t}}+\mathrm{e}_{1 \mathrm{t}} \\ \text { LnRICE }_{\mathrm{t}}= & \mathrm{b}_{0}+\mathrm{b}_{1} \text { LnRICE }_{\mathrm{t}-1}+ \\ & \mathrm{b}_{2} \text { LnInflasi }_{\mathrm{t}}+\end{aligned}$

$\mathrm{b}_{3} \mathrm{LnRC}_{\mathrm{t}}+\mathrm{b}_{4} \mathrm{LnCO}_{\mathrm{t}}$

$+b_{5} \mathrm{LnCM}_{\mathrm{t}}+$

$\mathrm{b}_{6} \operatorname{LnBE}_{t}+$ $\mathrm{b}_{7} \operatorname{LnCorn}_{\mathrm{t}}+\mathrm{e}_{2 \mathrm{t}}$

$\mathrm{LnRC}_{\mathrm{t}}=\mathrm{C}_{0}+\mathrm{c}_{1} \mathrm{LnRC}_{\mathrm{t}-1}+$ $\mathrm{c}_{2}$ LnInflasit + $\mathrm{C}_{3}$ LnRICE $_{t}+$ $\mathrm{C}_{4} \mathrm{LnCO}_{\mathrm{t}}+\mathrm{C}_{5} \mathrm{LnCM}_{\mathrm{t}}$ $+\mathrm{c}_{6} \mathrm{LnBE}_{\mathrm{t}}+$ $\mathrm{C}_{7} \mathrm{LnCorn}_{\mathrm{t}}+\mathrm{e}_{3 \mathrm{t}}$

$\mathrm{LnCO}_{\mathrm{t}}=\mathrm{d}_{0}+\mathrm{d}_{1} \mathrm{LnCO}_{\mathrm{t}-1}+$ $\mathrm{d}_{2}$ LnInflasit $_{t}+$ $\mathrm{d}_{3}$ LnRICE $_{\mathrm{t}}+$ $\mathrm{d}_{4} \mathrm{LnRC}_{\mathrm{t}}+$ $\mathrm{d}_{5} \operatorname{LnCM}_{\mathrm{t}}+$ $\mathrm{d}_{6} \operatorname{LnBE}_{\mathrm{t}}+$ $\mathrm{d}_{7} \operatorname{LnCorn}_{\mathrm{t}}+\mathrm{e}_{4 \mathrm{t}}$

LnCM $_{\mathrm{t}}=\mathrm{e}_{0}+\mathrm{e}_{1}$ LnCM $_{\mathrm{t}-1}$ $+\mathrm{e}_{2}$ LnInflasit + $\mathrm{e}_{3}$ LnRICE $_{t}+$ $\mathrm{e}_{4} \mathrm{LnRC}_{\mathrm{t}}+\mathrm{e}_{5} \mathrm{LnCO}_{\mathrm{t}}$ $+\mathrm{e}_{6} \mathrm{LnBE}_{\mathrm{t}}+$ $\mathrm{e}_{7} \mathrm{LnCorn}_{\mathrm{t}}+\mathrm{e}_{5 \mathrm{t}}$

$\mathrm{LnBE}_{\mathrm{t}} \quad=\mathrm{f}_{0}+\mathrm{f}_{1} \operatorname{LnBE}_{\mathrm{t}-1}+$ $\mathrm{f}_{2}$ LnInflasit + $\mathrm{f}_{3}$ LnRICE $_{t}+$ $\mathrm{f}_{4} \mathrm{LnRC}_{\mathrm{t}}+\mathrm{f}_{5} \mathrm{LnCO}_{\mathrm{t}}$ $+\mathrm{f}_{6} \mathrm{LnCM}_{t}+$ $\mathrm{f}_{7} \mathrm{LnCorn}_{\mathrm{t}}+\mathrm{e}_{6 \mathrm{t}}$

LnCORN $_{\mathrm{t}}=\mathrm{g}_{0}+\mathrm{g}_{1}$ LnCornt $_{\mathrm{t}-1}+$ $\mathrm{g}_{2}$ LnInflasit + $\mathrm{g}_{3} \mathrm{LnRICE}_{t}+$ $\mathrm{g}_{4} \mathrm{LnRC}_{\mathrm{t}}+\mathrm{g}_{5} \mathrm{LnCO}_{\mathrm{t}}$ $+\mathrm{g}_{6} \mathrm{LnCM}_{\mathrm{t}}+$ $\mathrm{g}_{7} \mathrm{LnBE}_{\mathrm{t}}+\mathrm{e}_{7 \mathrm{t}}$

\begin{tabular}{|c|c|}
\hline nana & \\
\hline LnInflasit & 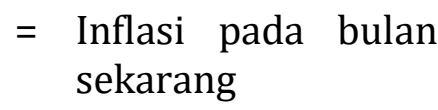 \\
\hline $\begin{array}{l}\text { LnInflasit- } \\
1\end{array}$ & $=\begin{array}{l}\text { Inflasi pada bulan } \\
\text { sebelumnya }\end{array}$ \\
\hline LnRice $_{t}$ & $\begin{aligned} &= \text { Harga beras pada } \\
& \text { bulan sekarang }\end{aligned}$ \\
\hline LnRice $_{\mathrm{t}-1}$ & $\begin{array}{l}=\text { Harga beras pada } \\
\text { bulan sebelumnya }\end{array}$ \\
\hline $\mathrm{LRC}_{\mathrm{t}}$ & $\begin{aligned} \text { Harga cabai merah } & \begin{array}{l}\text { pada } \\
\text { sekarang }\end{array}\end{aligned}$ \\
\hline
\end{tabular}




\begin{tabular}{|c|c|c|}
\hline $\mathrm{LRC}_{\mathrm{t}-1}$ & $=$ & $\begin{array}{l}\text { Harga cabai merah } \\
\text { pada } \\
\text { sebelumnya }\end{array}$ \\
\hline $\mathrm{LnCO}_{\mathrm{t}}$ & $=$ & $\begin{array}{l}\text { Harga minyak } \\
\text { goreng pada bulan } \\
\text { sekarang }\end{array}$ \\
\hline $\operatorname{LnCO}_{\mathrm{t}-1}$ & $=$ & $\begin{array}{l}\text { Harga minyak } \\
\text { goreng pada bulan } \\
\text { sebelumnya }\end{array}$ \\
\hline $\mathrm{LnCM}_{\mathrm{t}}$ & $=$ & $\begin{array}{l}\text { Harga daging ayam } \\
\text { pada } \\
\text { sekarang }\end{array}$ \\
\hline $\operatorname{LnCM}_{\mathrm{t}-1}$ & $=$ & $\begin{array}{l}\text { Harga daging ayam } \\
\text { pada } \\
\text { sebelumnya }\end{array}$ \\
\hline $\mathrm{LnBE}_{\mathrm{t}}$ & $=$ & $\begin{array}{l}\text { Harga telur ayam } \\
\text { ras pada bulan } \\
\text { sekarang }\end{array}$ \\
\hline $\operatorname{LnBE}_{\mathrm{t}-1}$ & $=$ & $\begin{array}{l}\text { Harga telur ayam } \\
\text { ras pada bulan } \\
\text { sebelumnya }\end{array}$ \\
\hline $\operatorname{LnCorn}_{\mathrm{t}}$ & $=$ & $\begin{array}{l}\text { Harga jagung pada } \\
\text { bulan sekarang }\end{array}$ \\
\hline $\operatorname{LnCorn}_{\mathrm{t}-1}$ & & $\begin{array}{l}\text { Harga jagung pada } \\
\text { bulan sebelumnya }\end{array}$ \\
\hline $\begin{array}{l}\text { a } 0 \ldots g_{7} \\
\text { et } 1 \ldots \text { et7 }\end{array}$ & $\begin{array}{l}= \\
=\end{array}$ & $\begin{array}{l}\text { Parameter estimasi } \\
\text { Error term }\end{array}$ \\
\hline
\end{tabular}

Tahapan Model Vector
Spesifikasi model VAR meliputi pemilihan variabel dan penentuan lag setiap variabel endogen. Terdapat beberapa tahapan dalam melakukan analisis VAR, yaitu: (1) Uji Stasioneritas Data; (2) Uji Stabilitas Model VAR; (3) Uji Kointegrasi; (4) Estimasi Vector Error Corection Model (VECM); (5) Analisis Impulse Response Function (IRF); dan (6) Analisis Forecast Error Variance Decomposition (FEVD).

\section{HASIL DAN PEMBAHASAN Uji Stasioneritas Data}

Berdasarkan hasil uji stasioneritas pada variabel inflasi, beras, cabai merah, minyak goreng, daging ayam, telur ayam ras dan jagung dimana semua variabel mengalami stationer artinya memiliki nilai rata-rata dan varians yang konstan sepanjang waktu, hal ini ditunjukkan nilai ADF statistik pada semua variabel lebih kecil daripada MacKinnon critical value. Hal ini data sudah stasioner pada first difference.

Tabel 1. Hasil Uji Stasioneritas Data

\begin{tabular}{lccccc}
\hline \multirow{2}{*}{ Variabel } & ADF & \multicolumn{3}{c}{ MacKinnon Critical Value } & \multirow{2}{*}{ Keterangan } \\
& Statistic & $\mathbf{1 \%}$ & $\mathbf{5 \%}$ & $\mathbf{1 0 \%}$ & \\
\hline LnINF & $-15,38139$ & $-3,457630$ & $-2,873440$ & $-2,573187$ & Stasioner \\
LnBRS & $-24,41886$ & $-3,457630$ & $-2,873440$ & $-2,573187$ & Stasioner \\
LnDAR & $-11,69918$ & $-3,457984$ & $-2,873596$ & $-2,573270$ & Stasioner \\
LnCAM & $-15,59593$ & $-3,457630$ & $-2,873440$ & $-2,573187$ & Stasioner \\
LnMKG & $-26,22511$ & $-3,457630$ & $-2,873440$ & $-2,573187$ & Stasioner \\
LnTAR & $-7,818471$ & $-3,457865$ & $-2,873543$ & $-2,573242$ & Stasioner \\
LnJAG & $-23,56726$ & $-3,457630$ & $-2,873440$ & $-2,573187$ & Stasioner \\
\hline
\end{tabular}

Sumber: Data diolah dengan Eviews10, 2019.

\section{Uji Stabilitas Model VAR}

Pengujian stabilitas VAR dilakukkan dengan menguji akar-akar dari fungsi polinominal atau roots of characterstic polinominal. Estimasi VAR stabil apabila seluruh roots memiliki modulus $<1$ dan berada dalam unit circle. Kestabilan model 
VAR menghasilkan estimasi Impulse Response Functions (IRF) dan Forecast Error Variance Decomposition (FEVD) dianggap valid. Hasil outputnya dapat dilihat pada Tabel 2. Pada tabel tersebut menampilkan bahwa nilai modulus $<1$, sehingga estimasi VAR stabil.

Tabel 2. Hasil Uji Stabilitas VAR

\begin{tabular}{ll}
\hline Root & Modulus \\
\hline$-0,539694-0,205264 \mathrm{i}$ & 0,577411 \\
$-0,539694+0,205264 \mathrm{i}$ & 0,577411 \\
$-0,320924-0,391034 \mathrm{i}$ & 0,505865 \\
$-0,320924+0,391034 \mathrm{i}$ & 0,505865 \\
$0,175356-0,335967 \mathrm{i}$ & 0,378977 \\
$0,175356+0,335967 \mathrm{i}$ & 0,378977 \\
$-0,058013-0.338144 \mathrm{i}$ & 0,343084 \\
$-0,058013+0,338144 \mathrm{i}$ & 0,343084 \\
$-0,322727$ & 0,322727 \\
$0,039259-0,289374 \mathrm{i}$ & 0,292025 \\
$0,039259+0,289374 \mathrm{i}$ & 0,292025 \\
0,217142 & 0,217142 \\
$-0,126785-0,167503 \mathrm{i}$ & 0,210075 \\
$-0,126785+0,167503 \mathrm{i}$ & 0,210075 \\
\hline
\end{tabular}

Sumber: Data diolah dengan Eviews10, 2019.

\section{Uji Kointegrasi}

Hasil uji kointegrasi untuk mengetahui keberadaan informasi hubungan jangka panjang antar variabel. Jika terdapat kointegrasi, maka analisis selanjutnya menggunakan VECM. Namun, apabila tidak terdapat kointegrasi maka analisis dilanjutkan dengan menggunakan VAR. Kriteria yang digunakan dalam uji kointegrasi pada penelitian ini adalah Johansen Cointegration Test. Suatu model dinyatakan memiliki kointegrasi apabila nilai trace statistic lebih besar daripada critical value.

Tabel 3. Hasil Johansen Cointegration Test

\begin{tabular}{ccccc}
\hline $\begin{array}{c}\text { Hypothesized } \\
\text { No. of CE(s) }\end{array}$ & Eigenvalue & Trace Statistic & $\begin{array}{c}\mathbf{0 . 0 5} \text { Critical } \\
\text { Value }\end{array}$ & Prob.** \\
\hline None & 0,562942 & 704,0277 & 125,6154 & 0,0001 \\
At most $1^{*}$ & 0,440303 & 507,8652 & 95,75366 & 0,0001 \\
At most 2 & 0,361354 & 370,3202 & 69,81889 & 0,0001 \\
At most $3^{*}$ & 0,302501 & 264,0482 & 47,85613 & 0,0001 \\
At most 4 & 0,243270 & 178,6681 & 29,79707 & 0,0001 \\
At most 5 & 0,217711 & 112,6048 & 15,49471 & 0,0001 \\
At most 6 & 0,205144 & 54,41397 & 3,841466 & 0,0000 \\
\hline
\end{tabular}

Sumber: Data diolah dengan Eviews10, 2019.

Berdasarkan hasil Tabel 3, besar dari critical value. Dengan menunjukkan bahwa pada selang kepercayaan 5\% semua persamaan memiliki nilai trace statistic yang lebih demikian terdapat tujuh persamaan yang kointegrasi, sehingga ada 
hubungan jangka panjang diantara variable.

\section{Estimasi Vector Error Corection Model (VECM)}

VECM menunjukkan pengaruh fluktuasi harga masing-masing komoditas pangan terhadap inflasi di Provinsi Sumatera Utara dalam jangka pendek dan jangka panjang. Pengujian signifikan pada hasil estimasi dilakukan dengan cara membandingkan nilai t-hitung $>$ nilai t-tabel maka dapat dikatakan memiliki pengaruh yang signifikan dan sebaliknya jika nilai t-hitung < nilai t-tabel maka dapat dikatakan memiliki pengaruh yang tidak signifikan. Dimana nilai t-hitung atau nilai statistik yang digunakan merupakan nilai mutlaknya yang dibandingkan dengan nilai t-tabel.

Tabel 4. Hasil estimasi VECM di Provinsi Sumatera Utara

\begin{tabular}{lcccc}
\hline \multicolumn{1}{c}{ Variabel } & Koefisien & $\begin{array}{c}\text { T-Statistik } \\
\text { Jangka Pendek }\end{array}$ & T-Tabel (5\%) & Intepretasi \\
\hline CointEq1 & $-0,078462$ & {$[-1,90953]$} & 1,65251 & Signifikan \\
D(INF(-1)) & $-0,601487$ & {$[-8,60242]$} & 1,65251 & Signifikan \\
D(INF(-2)) & $-0,301794$ & {$[-4,31285]$} & 1,65251 & Signifikan \\
D(BRS(-1)) & 0,327287 & {$[1,91405]$} & 1,65251 & Signifikan \\
D(BRS(-2)) & 0,144725 & {$[1,18621]$} & 1,65251 & Tidak Signifikan \\
D(DAR(-1)) & 0,024749 & {$[0,52919]$} & 1,65251 & Tidak Signifikan \\
D(DAR(-2)) & $-0,000691$ & {$[-0,01512]$} & 1,65251 & Tidak Signifikan \\
D(CAM(-1)) & $-0,042991$ & {$[-1,76936]$} & 1,65251 & Signifikan \\
D(CAM(-2)) & $-0,012621$ & {$[-0,54923]$} & 1,65251 & Tidak Signifikan \\
D(MKG(-1)) & 0,049915 & {$[0,47313]$} & 1,65251 & Tidak Signifikan \\
D(MKG(-2)) & 0,015633 & {$[0,14861]$} & 1,65251 & Tidak Signifikan \\
D(TAR(-1)) & $-0,123957$ & {$[-1,22505]$} & 1,65251 & Tidak Signifikan \\
D(TAR(-2)) & $-0,085823$ & {$[-1,04653]$} & 1,65251 & Tidak Signifikan \\
D(JGG(-1)) & $-0,020177$ & {$[-0,19167]$} & 1,65251 & Tidak Signifikan \\
D(JAG(-2)) & 0,015398 & {$[0,15065]$} & 1,65251 & Tidak Signifikan \\
C & $-0,007282$ & {$[-0,00811]$} & 1,65251 & Tidak Signifikan \\
& & Jangka Panjang & & \\
Variabel & Koefisien & T-Statistik & & \\
INFLASI (-1) & 1,000000 & - & & \\
(BRS(-1)) & 4,818359 & {$[10,4479]$} & 1,65251 & Signifikan \\
(DAR(-1)) & 0,409859 & {$[2,21696]$} & 1,65251 & Signifikan \\
(CAM(-1)) & $-0,395696$ & {$[-5,74585]$} & 1,65251 & Signifikan \\
(MKG(-1)) & 0,703471 & {$[1,73054]$} & 1,65251 & Signifikan \\
(TAR(-1)) & $-2,180872$ & {$[-6,85543]$} & 1,65251 & Signifikan \\
(JAG(-1)) & $-0,164748$ & {$[-0,36756]$} & 1,65251 & Tidak Signifikan \\
C & 1,700352 & - & & \\
\hline
\end{tabular}

Sumber: Data diolah dengan Eviews10, 2019.

Adanya mekanisme penyesuaian dari jangka pendek ke jangka panjang ditunjukkan dengan adanya dugaan parameter error correction
(CoeintEq1) yang bernilai negatif. Model error correction dinyatakan valid dan stabil jika nilai parameternya adalah negatif dengan 
nilai absolut kurang dari satu dan signifikan. Interpretasi dari nilai error correction sebesar -0.078462, yaitu terdapat penyesuaian dari jangka pendek ke jangka panjang pada inflasi di Provinsi Sumatera Utara yang dikoreksi setiap bulannya sebesar $0.078 \%$.

Berdasarkan hasil Tabel 4 pada jangka pendek terdapat empat variabel yang mempengaruhi inflasi pada periode sekarang secara signifikan pada taraf $5 \%$ yaitu inflasi satu bulan sebelumnya, inflasi dua bulan sebelumnya, harga beras satu bulan sebelumnya dan harga cabai merah satu bulan sebelumnya.

Sedangkan pada jangka panjang terdapat variabel yang mempengaruhi inflasi yaitu harga beras, harga daging ayam ras, harga cabai merah, harga minyak goreng dan harga telur ayam ras. Variabel-variabel tersebut dikatakan memiliki pengaruh yang signifikan terhadap inflasi karena nilai t-statistik masing-masing variabel tersebut lebih besar dari t-tabel sebesar 1.65251.

Hasil penelitian ini sesuai dengan
Kusnadi (2018) dimana harga beras, harga daging ayam, harga cabe rawit berpengaruh positif dan signifikan terhadap inflasi di Jawa Timur. Dengan demikian inflasi harga pangan pada jangka panjang maupun jangka pendek tetap menjadi pendorong yang signifikan untuk inflasi harga konsumen secara keseluruhan dan harga pangan di Provinsi Sumatera Utara.

\section{Analisis Impulse Response Function (IRF)}

Impulse Response Function (IRF) digunakan untuk melihat efek dari gejolak (shock) suatu standar deviasi dari variabel baru terhadap nilai sekarang (current time values) dan nilai yang datang (future values) dari model yang diamati. Pada peneltian ini hasil uji IRF ditampilkan dalam bentuk tabel yang dijelaskan dalam jangka waktu 60 bulan ke depan dari periode penelitian. Kemudian dilihat dalam tiga periode jangka waktu yaitu jangka pendek (12 bulan awal), jangka menengah (bulan ke-13 sampai ke36) dan jangka panjag (bulan ke-37 sampai ke-60).

Tabel 5. Hasil IRF Inflasi di Provinsi Sumatera Utara

\begin{tabular}{ccrrrrrc}
\hline No. & INF & BRS & \multicolumn{1}{c}{ DAR } & CAM & MKG & TAR & JAG \\
\hline 1 & 13,83046 & 0,000000 & 0,000000 & 0,000000 & 0,000000 & 0,000000 & 0,000000 \\
12 & 6,549809 & $-0,532372$ & $-0,142576$ & 0,423357 & $-0,004684$ & 0,462131 & 0,056464 \\
13 & 6,534326 & $-0,539415$ & $-0,162436$ & 0,439628 & $-0,027576$ & 0,541093 & 0,041310 \\
36 & 6,537534 & $-0,538378$ & $-0,150515$ & 0,444842 & $-0,022297$ & 0,512218 & 0,054995 \\
37 & 6,537603 & $-0,538384$ & $-0,150450$ & 0,444848 & $-0,022323$ & 0,512173 & 0,055065 \\
60 & 6,537574 & $-0,538392$ & $-0,150469$ & 0,444836 & $-0,022294$ & 0,512153 & 0,055051 \\
\hline
\end{tabular}

Sumber: Data diolah dengan Eviews10, 2019.

Hasil IRF yang memberikan respon yang besar terhadap inflasi adalah harga telur ayam ras. Jangka pendek shock harga telur ayam ras dimana direspon oleh inflasi, naik dari 0.000000 sampai 0.462131 . Setiap 
satu standar deviasi terjadi shock harga telur ayam ras dimana direspon oleh inflasi hingga naik sebesar 0.462131 satu-satuan. Respon kenaikan inflasi bukanlah disebabkan dominan oleh komoditi beras karena beras merupakan salah satu makanan pokok masyarakat dan ketersediaannya yang selalu cukup oleh pemerintah, sedangkan telur ayam ras mengandung protein yang tinggi sehingga permintaan masyarakat selalu meningkat dan akhirnya dapat mengakibatkan inflasi.

Jangka menengah setiap satu standar devisiasi terjadi shock harga telur ayam ras dimana direspon oleh inflasi, naik dari 0.541093 sampai 0.512218. Setiap satu standar devisiasi terjadi shock harga telur ayam ras dimana direspon oleh inflasi hingga naik 0.512218 satu-satuan.

Jangka panjang setiap satu standar devisiasi terjadi shock harga telur ayam ras dimana direspon oleh inflasi, naik dari 0.512173 sampai 0.512153. Setiap satu standar devisiasi terjadi shock harga telur ayam ras dimana direspon oleh inflasi hingga naik 0.512153 satu-satuan. Hasil penelitian ini sesuai dengan Ardiyanti dan Juliprijanto (2020) menemukan bahwa daging ayam ras dan cabai rawit merupakan komoditas pangan yang harganya memberikan respon terbesar dan signifikan terhadap inflasi di kota Magelang dalam jangka pendek dan panjang.

\section{Analisis Forecast Error Variance Decomposition (FEVD)}

Analisis FEVD bertujuan untuk memprediksi kontribusi persentase varian setiap komoditas pangan karena adanya guncangan harga yang diteliti dalam menjelaskan keragaman inflasi tersebut (Bank Indonesia, 2018).

Tabel 6. Hasil Analisis Forecast Error Variance Decomposition (FEVD)

\begin{tabular}{ccccccccc}
\hline Bulan & S.E. & INF & BRS & DAR & CAM & MKG & TAR & JAG \\
\hline 1 & 13.830 & 100.000 & 0.000 & 0.000 & 0.000 & 0.000 & 0.000 & 0.000 \\
12 & 25.433 & 98.325 & 0.587 & 0.054 & 0.490 & 0.003 & 0.521 & 0.019 \\
13 & 26.274 & 98.314 & 0.592 & 0.054 & 0.487 & 0.003 & 0.531 & 0.018 \\
36 & 41.124 & 98.255 & 0.636 & 0.053 & 0.469 & 0.002 & 0.573 & 0.011 \\
37 & 41.649 & 98.254 & 0.637 & 0.053 & 0.468 & 0.002 & 0.574 & 0.011 \\
60 & 52.303 & 98.240 & 0.648 & 0.052 & 0.463 & 0.002 & 0.585 & 0.010 \\
\hline
\end{tabular}

Sumber: Data diolah dengan Eviews10, 2019.

Berdasarkan hasil analisis FEVD, ada tiga komoditas yang paling dominan dalam menjelaskan keragaman inflasi di Provinsi Sumatera Utara, yaitu harga beras (BRS), harga telur ayam ras (TAR) dan harga cabai merah (CAM). Jangka pendek, nilai harga beras (BRS) berkisar antara 0,000\% - 0,587\%, harga telur ayam ras (TAR) berkisar antara 0,000\% - 0,521\% dan harga cabai merah (CAM) berkisar antara 0,000\% - 0,490\%. Artinya kontribusi harga beras lebih dominan dibandingkan dengan harga telur ayam ras dan harga cabe merah 
terhadap inflasi di Provinsi Sumatera Utara yaitu sebesar 0,587 persen,

Jangka menengah, nilai harga beras (BRS) berkisar antara 0,592\% $0,636 \%$, harga telur ayam ras (TAR) berkisar 0,531\% - 0,573\% dan harga cabai merah (CAM) berkisar antara $0,487 \%-0,053 \%$. Artinya kontribusi harga beras lebih dominan dibandingkan dengan harga telur ayam ras dan harga cabe merah terhadap inflasi di Provinsi Sumatera Utara yaitu sebesar 0,636 persen,

Jangka panjang, nilai harga beras (BRS) sekitar 0,637\% - 0,648\%, TAR sekitar $0,574 \%-0,585 \%$ dan harga cabai merah (CAM) sekitar 0,468\% $0,463 \%$. Artinya kontribusi harga beras lebih dominan dibandingkan dengan harga telur ayam ras dan harga cabe merah terhadap inflasi di Provinsi Sumatera Utara yaitu sebesar 0,648 persen, Dalam jangka panjang permintaan beras, telur ayam ras dan cabai merah masih tinggi akibat adanya peningkatan jumlah penduduk, pendapatan masyarakat dan pentingnya konsumsi pangan bagi rumah tangga, baik dipedesaan maupun perkotaan sehingga dapat mendorong inflasi di Provinsi Sumatera Utara.

Hasil penelitian ini sesuai Setiawan (2015) dimana hasil analisis VAR menunjukkan bahwa dalam jangka pendek hanya komoditas cabai merah kriting yang berdampak secara signifikan terhadap inflasi di Provinsi Banten. Pada jangka panjang terdapat enam komoditas yang berdampak secara signifikan terhadap inflasi di
Provinsi Banten, yaitu daging sapi murni, jagung, beras, daging ayam ras, telur yam ras serta cabai merah keriting.

\section{SIMPULAN}

Jangka pendek terdapat beberapa variabel yang mempengaruhi inflasi di Provinsi Sumatera Utara yaitu inflasi bulan sebelumnya, harga beras bulan sebelumnya dan harga cabe merah bulan sebelumnya. Sedangkan jangka panjang inflasi dipengaruhi oleh harga beras bulan sebelumnya, harga daging ayam ras bulan sebelumnya, harga cabe merah bulan sebelumnya, minyak goring bulan sebelumnya, dan telur ayam ras bulan sebelumnya. Variabel tersebut memiliki pengaruh yang signifikan terhadap inflasi karena nilai t-statistik lebih besar dari t-tabel. Komoditas pangan yang paling dominan dalam menjelaskan keragaman inflasi di Provinsi Sumatera Utara dari yang paling besar pengaruhnya ke yang paling kecil adalah harga beras, harga telur ayam ras, harga cabai merah, harga daging ayam ras, harga jagung dan harga minyak goreng. Saran penelitian lanjutan menggunakan model dan variabel yang berbeda untuk menganalisis pengaruh harga pangan terhadap inflasi, seperti: harga bawang putih, harga cabe rawit dengan model Policy Accounting Matrix (PAM), dan model lainnya.

\section{Ucapan Terima Kasih}

Kami ingin mengucapkan terima kasih kepada DRPM Kementerian 
Riset, Teknologi, dan Pendidikan Tinggi (KEMENRISTEKDIKTI) sebagai lembaga yang telah mendanai penelitian ini melalui skema Riset Tesis Magister 2019 dengan kontrak No. 46/ UN5.2.3.1/PPM/KP RPM/2019. Selain itu kepada Lembaga Penelitian Universitas Sumatera Utara, yang telah berkontribusi secara moral dan material dalam pelaksanaan penelitian ini.

\section{DAFTAR PUSTAKA}

Ardiyanti, D.S. dan W. Juliprijanto. 2020. Kontribusi Harga Komoditas Pangan Terhadap Inflasi di Kota Magelang. Jurnal Paradigma Multidisplin (JPM). Vol. 1 Nomor 1. Magelang.

Apriyadi, R. dan Hutajulu, D.M. 2020. Pengaruh Harga Komoditas Pangan Hewani Asal Ternak Terhadap Inflasi di Provinsi DI Yogyakarta. Jurnal Ekonomi Bisnis dan Manajemen (Ecobisma), Vol. 7 No. 2. Universitas Labuhanbatu, Sumatera Utara.

Bank Indonesia. 2018. Inflasi. Bank Indonesia.

https://www.bi.go.id/id/monet er/inflasi/pengenalan/Contents /Disagregasi.aspx

Badan Pusat Statistik. 2018. Consumer Price Indices of Four Citiesin Sumatera Utara Province 2017. Badan Pusat Statistik Provinsi Sumatera Utara. Medan

Badan Pusat Statistik. 2018. Indeks Harga Konsumen di Empat Kota Provinsi Sumatera Utara 2017. Katalog: 7102023.12. Badan Pusat Statistik Provinsi Sumatera Utara. Medan.
Budiono. 2000. Ekonomi Moneter, Edisi 3. BPFE: Yogyakarta

Hakim, dkk. 2018. Dampak Kenaikan Harga Komoditas Sembako Terhadap Tingkat Inflasi di Indonesia. Prosiding Seminar Nasional dan Call for Papers Manajemen, Akuntansi, dan Perbankan, Vol 1 No 1.

Kusnadi, N.A. 2017. Pengaruh Fluktuasi Harga Komoditi Pangan Terhadap Inflasi di Jawa Timur. Skripsi, Fakultas Ekonomi dan Bisnis. Universitas Brawijaya, Malamg.

Mankiw. 2005. Teori Makro Ekonomi. Penerbit Erlangga, Jakarta.

Nurmapika, R. Nurliza dan Imelda. 2018. Analisis Volatilitas Harga Pangan Strategis di Provinsi Kalimantan Barat. Journal Social Economic of Agriculture, Volume 7, Nomor 1, April 2018. Universitas Tanjungpura, Pontianak.

Rizaldy, D.Z. 2017. Pengaruh Harga Komoditas Pangan Terhadap Inflasi Di Kota Malang Pada Tahun 2011 - 2016. Jurnal Ekonomi Pembangunan, Vol. 15, No. 2. Departement of Economic Science and Development Studies. Universitas Muhammadiyah Malang.

Santoso, T. 2011. Aplikasi Model GARCH Pada Data Inflasi Bahan Makanan Indonesia Periode 2005. Jurnal Organisasi Manajemen. Vol 5, No. 1.

Setiawan A F. 2015. Fluktuasi Harga Komoditas Pangan dan Dampaknya Terhadap Inflasi di Provinsi Banten. Journal of Agriculture, Resource, and Environmental Economics), IPB Bogor 
Siregar, W.P. 2020. Analisis Pengaruh Harga Komoditi Pangan Terhadap Inflasi di Kota Sibolga. Skripsi Fakultas Pertanian, Universitas Sumatera Utara, Medan.

Suseno, et. al. 2009. Inflasi Seri Kebangsentralan. Pusat
Pendidikan dan Studi Kebangsentralan (PPSK) Bank Indonesia, Jakarta.

Tirtawinata, T.C. 2006. Makanan Dalam Perspektif Al-Qur'an dan Ilmu Gizi. Balai Penerbitan FKUI. Jakarta. 